\title{
Introduction. Four Decades of Independence: The Multiple Cultures of Portuguese-speaking Africa
}

\author{
PHILLIP ROTHWELL \\ University of Oxford \\ ANA MARIA MARTINHO \\ Universidade Nova de Lisboa
}

In the four decades since the independence of Portugal's African colonies, the world has changed in ways that in the 1970s could scarcely have been imagined. The Cold War politics that lurked in the background of the 1960s struggles for independence took center stage in the 1970s and 1980s as Mozambique and Angola stumbled into civil wars that fused with proxy-conflicts between the USA and USSR. Cabo Verde and Guinea-Bissau's improbable joint statehood ruptured in 1980, and the two political entities took very different paths that reflected very different experiences of colonialism. For its part, São Tomé e Príncipe initially followed a socialist trajectory, nationalizing the plantations, before a post-Cold War constitution heralded multiparty politics underpinned by capitalism.

The former colonies' roads to statehood were very arduous. Their military struggles for independence hastened the demise of the Portuguese New State, so that liberation in Africa will always be inextricably linked to liberation in Portugal. The New State's NATO membership and the independence movements' links with the Portuguese Communist Party had tilted the first leaders of the new nations towards alliances with the Soviet bloc. With the fall 
of the Berlin Wall, the geopolitical rules changed, and the independent states adapted to the new circumstances of a neoliberal world order-an order that is increasingly contested within and beyond Africa. What is remarkable particularly in Angola and Mozambique is the extent to which the ruling parties, Frelimo and the MPLA, retained and strengthened their grips on power even in the aftermath of the USSR's collapse.

Forty years since the end of Portuguese colonialism, does it still make sense to consider Portuguese-speaking Africa as a unit of analysis? One of the concerns when editing a volume on Portuguese-speaking Africa is, as the late Patrick Chabal often warned, falling prey to false comparison. When we talk about Portuguese-speaking Africa and look at the five independent states as a group, are we reinforcing a colonial paradigm? And are we missing more productive vectors of comparison? Chabal, one of the pioneers of Lusophone African Studies in the English-speaking world, repeatedly reminded us that other comparisons between and within regional groupings, crossing official language boundaries, often make more sense. One of the articles in this volume, Ana Salgueiro Rodrigues's "Encounters and Silence between Fathers and Sons: G.T. Didial and J.M. Coetzee" attempts such a cross-language and cross-regional comparison between one of Cabo Verde's most innovative writers, João Varela (who used the heteronym G.T. Didial), and the South African Nobel prize winner, Coetzee.

Didial's work often dialogues with the nature of Cabo Verde as a collection of islands. Of all Portugal's former African colonies, it has made the most postindependence progress, in terms of indices of human development and freedom of expression. Much of the cultural output of Cabo Verde has focused on its status as an archipelago, a status that detached it from the African continent, giving it a very distinct outlook on its place in the region and the world. Similarly, São Tomé e Príncipe's insularity and relatively small population size (fewer than 200,000 inhabitants) has shaped its development as a nation. Despite its strong historical links to Angola, through a colonial system of slavery and forced labor, São Tomé e Príncipe, like Cabo Verde, has often seen its island status as a source of isolation and difference, as well as creating a nexus linking it to a diaspora around the globe. Joana Castaño's article, "The Island in Conceição Lima's Poetry," discusses how one of São Tomé e Príncipe's most important contemporary poets interacts with the islands-as-islands as a locus of her home, and how the African 
continent interplays with the affect the poetic voice has for the country of her birth.

The very different sizes and histories of Portugal's former island colonies in comparison with those on the African mainland lend weight to Chabal's warning against privileging "Lusophone" Africa as a category to the detriment of other equally productive ways of viewing the politics and cultures of Angola, Cabo Verde, Guinea-Bissau, Mozambique, and São Tomé e Príncipe. At the same time, there is no denying that the five states do have a partially shared experience, based on a heritage of Portuguese influence and that, four decades ago, the nature of that influence transformed forever with independence.

The global political changes of the last forty years have been matched by unparalleled developments in the cultural sphere. As much as anything else, the advance of the communication economy and the advent of the world wide web have connected parts of Africa, particularly its aspiring youth, in ways hitherto unimaginable. That same youth have no lived experience of the struggles for independence. For them, their rulers are not heroes who defeated the Portuguese and gave birth to new nations, but politicians who in some cases have been in power for a very long time. The cultural sphere of the young is increasingly a space where the "nation" is contested rather than "forged," as was the case during the early years following independence (Peres). Many of the leaders of the independence movements understood culture as a mechanism for creating a unified national identity. As recent developments in Portuguese-speaking African culture demonstrate, any sense of nationhood must be understood in its diversity as a constantly evolving concept.

While Cabo Verde and São Tomé e Príncipe are very much defined by their relatively homogenous nature as islands with small populations and a large diaspora, Angola and Mozambique are bigger and much more diverse countries, with multiple traditions, languages, and ethnicities within their borders. One of the overarching tensions often overlooked in relation to the two countries is the marked division between cities and countryside. The increasing disconnect between urban elites and a forgotten rural mass is one of the most striking characteristics of contemporary Angola in particular. The way in which the MPLA won such a decisive victory in the Angolan civil war in 2002 exacerbated that split. With the elimination of their longstanding foe, Jonas Savimbi, the MPLA leadership have been able to dictate the terms of the peace without the 
need to reach an accommodation with their opponents (something Frelimo was forced to do, with an increasingly doubtful degree of success as the current slide back into conflict in Mozambique indicates).

Of all the Portuguese-speaking African ruling elites, the longevity of MPLA's hold on power in Angola is the most remarkable. It has undergone many ideological transformations over its existence. One constant from the MPLA's foundation onwards is its predominantly urban essence. As "the heir to the clubs, associations and newspapers which successive colonial regimes had suppressed" (Birmingham 74), the MPLA had a clear understanding of the role of culture in spawning a national sense of being. Many in its early leadership spent time at the Casa dos Estudantes do Império, a creation of the Salazar regime that sought to nurture the allegiance of the empire's elites but instead cultivated their nationalist sentiments and links with each other as well as with the Portuguese Communist Party. Alexandra Reza's article, "Back and Forth Between Unity and Division: African Anti-Colonialism and the Ultramarinos of the Casa dos Estudantes do Império," draws on archival research about Mensagem, the journal published by the Casa, as a way, in part, of reading the relationship between Lusophone and Francophone anti-colonial groups in another cross-linguistic comparison. In her article, "Angola, a Nation in Pieces in José Eduardo Agualusa's Estação das Chuvas," Raquel Ribeiro analyzes a novel that draws on the Mensagem generation to question the legitimacy of the MPLA through a narrative that flashes back to a time before party orthodoxy had stifled dissent.

For the MPLA, the city was always the lens through which they viewed the world. As anti-colonial consciousness grew, those who began to "write" a new Angolan nation, like Luandino Vieira and Pepetela, changed the definition of the city, expanding it beyond the tarmac-coated avenues of its colonial center to the diversity and chaos of its margins. At a cultural level, a strong strand of Angolan nationalism was, in part, born through the musseques, or Luanda's shanty-towns, powerfully depicted in Luandino's work.

Several of the articles in this volume analyze the role of the city in Portuguese-speaking Africa, underlining its continued importance in the cultural conception of the post-independence states. The prisons of Luanda as experienced by Luandino Vieira are the topic of Mónica Silva's "Luanda through its Prisons: Luandino Vieira's Papéis da Prisão." In her article, "Literary Voices of Luanda and Maputo-A Struggle for the City," Margarida Calafate Ribeiro 
traces the literary evolution of Angola and Mozambique's capital cities, comparing and contrasting the literary portraits of the two largest conurbations in Portuguese-speaking Africa. In "Luanda and Maputo: Accounts of the Two Capitals in Urban Heritage Discourse," Walter Rossa chooses the same geographical points of comparison but uses the framework of the cities' architectural heritage to understand, critique and come to terms with the legacies of Portuguese colonialism.

Given their commensurate size, Angola and Mozambique - and Luanda and Maputo-offer productive and intelligent points of comparison. Their marked differences as well as their communalities help us to understand the longevity of their two ruling parties. Where the MPLA was unashamedly urban, part of Frelimo's heritage and national appeal as an independence movement was based on an appreciation of the rural aspect of the nation they were building. Within the Mozambican nationalist mindset, the district of Mafalala-as an interface between the urban and the rural-has a particular cultural importance explored by both Francisco Noa, in "Mafalala: Memory of a Sociocultural Landscape" and Nuno Simão Gonçalves, in "The Urban Space of Mafalala: Origin, Evolution, and Characterization." Noa, who grew up in the Maputo neighborhood, recalls the experience of his childhood and argues that this cosmopolitan microcosm of the nation, and indeed the world, was ahead of its time. For his part, Gonçalves discusses the urban development of the district as a way of understanding how uniquely colonial structures gave rise to the cultural birthplace of the Mozambican nation.

The post-independence and post-conflict city continues to be a cultural locus where the nation is interrogated. For example, the films of Zezé Gamboa, Solveig Nordlund, and Maria João Ganga portray the city (Luanda or Maputo) as a megalopolis caught in the consequences of Angola and Mozambique's civil wars. There, urban elites appear to gain at the expense of a sacrificed population at large. A younger urban generation, repeating the example of those who fought for independence, use culture to critique the corruption and apparent impunity of a confident ruling class. Rappers like the Angolan MCK, with performances such as "Ghettos na vertical," challenge oligarchs once cloaked in the rhetoric of freedom fighters. Rap also has a particular resonance in Guinea-Bissau, as Federica Lupati discusses in her article "An Introduction to Hip-Hop Culture in Guinea-Bissau: The Guinean Raperu." As a form of resistance, the musical 
subculture has provided a venue to critique the political direction of a country that has suffered an uncomfortable number of military coups since independence. Now often linked by the international media with drug-trafficking, GuineaBissau has probably been the least successful of all Portugal's former colonies in building state institutions. Despite its instability, it has produced some of Africa's most innovative film-makers including Flora Gomes and Sana N'Hada, whose 2013 film Kadjike depicts the invasion of islands in the Bijagós archipelago by a gang of drug dealers.

Throughout Portuguese-speaking Africa, film has become a medium of critique and re-evaluation of the independence era. Virgem Margarida depicts the gendered brutality of the forced reeducation camps to which women from urban areas were sent against their will in the aftermath of the revolution. It indicts a policy that denigrated and objectified women in a way that continued the patriarchal legacy of colonialism. A similar legacy is discussed in the context of Angola by Julia Garraio in her article, "A Body to Make Luanda: The Black Woman from the Countryside in Angolan Literature," in which female objectification is traced through three time periods in Angolan literature.

Who knows what changes will happen over the next forty years, and how they will color our understanding of Portuguese-speaking Africa? The world will doubtless be a very different place. However, we are confident that the multiple cultures, histories and societies of these five distinct nations, while evolving in very different directions and forming synergies in different ways, will collectively continue to excite generations of scholars to come.

\section{Works Cited}

Birmingham, David. A Short History of Modern Angola. London: Hurst, 2015. Print.

Peres, Phyllis. Transculturation and Resistance in Lusophone African Narrative. Gainesville: U of Florida P, 1997. Print. 